\title{
Perancangan Ergonomis Pegangan Pendorong Kursi Roda Untuk Meninimasi Kesakitan Pergelangan Tangan
}

\author{
Designing Ergonomics Wheelchair Pusher Handle to Minimize Wrist Pain
}

\author{
Wawan Yudiantyo \\ Program Studi Teknik Industri, Universitas Kristen Maranatha \\ E-mail: wawanyudiantyo@yahoo.com
}

\begin{abstract}
Abstrak
Kursi roda merupakan sebuah alat untuk membantu pasien yang susah atau tidak bisa berjalan. Pendorong kursi roda merupakan orang yang membantu pasien tersebut untuk mendorong kursi rodanya ke tempat tertentu. Pada saat mendorong kursi roda, sering kali didapati pendorong merasa sakit pada pergelangan tangannya. Hal ini terjadi karena posisi pegangan/handle kursi roda yang ada terlalu lurus. Hal ini menyebabkan pergelangan tangan pendorong sakit. Terlebih lagi bila harus mendorong pada periode yang lama, pasien yang berbobot tubuh berat, jalan yang menanjak atau jalan yang menurun. Rasa sakit pada pergelangan tangan pendorong lebih disebabkan karena arah gaya dari pendorong tidak sejajar dengan arah pergerakan kursi roda.

Perancangan dimulai dengan studi literature berbasis Ergonomi, antara lain studi antropometri, fisiologi kerja ( sistem otot dan tulang ) dan pengamatan langsung. Kemudian, dirancang sebuah pegangan/handle tambahan yang mengarah vertikal, dipasangkan pada pegangan kursi roda. Dimana sudut pegangan/handle tersebut dapat dirubah dan disesuaikan dengan kenyamanan pendorong. Hal ini juga memperhatikan faktor keamanan, dimana pegangan/handle pendorong kursi roda dengan arah vertikal dapat lebih menahan kursi roda bila jalan yang dilalui menurun. Rancangan dilengkapi dengan penambahan busa agar pemegangan lebih nyaman.
\end{abstract}

Kata Kunci: Kursi roda, Pegangan/handle kursi roda, sudut gaya, kenyamanan.

\begin{abstract}
Wheelchair is one of devices to help patients who are difficult or unable to walk. A wheelchair pusher is a person who helps the patient to push his wheelchair to a certain place. When pushing a wheelchair, a pusher often feels pain in his/her wrist. This happens because the position of the wheelchair's handle is too straight. This causes the wrist pusher to hurt. Even more push for a long period of time, patients who have heavy body weight, uphill or downhill roads. The pain occured because the direction of the force of the pusher not being aligned with the direction of movement of the wheelchair.

The design begins with Ergonomics-based literature studies, including anthropometric studies, work physiology (muscular and bone systems) and direct observation. Then, an additional handle that is directed vertically is designed, attached to the wheelchair grip. Where the angle of the handle can be changed and adjusted to the comfort position of the pusher. It also takes into account the safety factor, where the wheelchair handle with vertical direction can better hold the wheelchair when the road is down. The design is equipped with the addition foam so that the handle more comfortable.
\end{abstract}

Keywords: Wheelchairs, wheelchair handles, angle offorce, comfort. 


\section{Pendahuluan}

Kursi roda merupakan sebuah fasilitas untuk membantu orang yang tidak bisa berjalan. Orang yang tidak bisa berjalan bisa dikarenakan sakit, lumpuh, lemah kaki, cacat kaki dan seterusnya. Kursi roda merupakan salah satu alat yang vital bagi mereka untuk melakukan perpindahan dari satu tempat ke tempat lainnya.

Dalam penggunaan kursi roda tersebut tidak jarang pengguna kursi roda tidak bisa mengayuh kursi rodanya melalui plang roda yang tersedia. Ini bisa terjadi karena ada cacat lengan atau lemah lengan dan seterusnya. Oleh karena itu dibutuhkan bantuan pendorong kursi roda.

Kalau kita perhatikan dengan seksama handle/pegangan pendorong pada kursi roda, posisinya lurus horizontal tegak lurus dengan batang sandaran kursi roda. Berdasarkan pengamatan pendahuluan 18 pendorong kursi roda, mereka sering merasakan kesakitan pada pergelangan tangannya. Kesakitan akan terasa sekali bila pendorong sedang mendorong kursi roda dengan frekuensi yang sering, durasi yang lama, jalanan yang menanjak/menurun, dan/atau pasien yang berat.

Dari pengamatan pendahuluan tersebut, perlu adanya sebuah penelitian untuk memberikan masukan mengenai rancangan pegangan yang tidak membuat cedera/sakit pendorong kursi roda pada saat mendorong kursi roda.

Perancangan tersebut meliputi dimensi dan posisi handle/pegangan pendorong kursi roda, penyebab timbulnya rasa sakit pada pergelangan tangan pada saat mendorong kursi roda, serta rancangan pegangan kursi roda baik dari dimensi, bentuk, posisi dan sudut/konturnya.

Tujuan dari penelitian ini ialah mengusulkan dan merancang sebuah pegangan kursi roda, baik dari bentuk, dimensi, posisi serta sudut/konturnya, agar pendorong tidak lagi merasakan sakit pada pergelangan tangannya pada saat mendorong kursi roda.

\section{Tinjauan pustaka}

Ergonomi, sebuah ilmu yang sistematis yang menggunakan data-data mengenai sifat, keterbatasan dan kemampuan manusia dalam merancang suatu sistem kerja, supaya manusia dapat bekerja dalam sistem tersebut secara optimal dalam arti baik, aman, nyaman,tepat, mudah dan memberikan kepuasan. Baik dalam arti memberikan manfaat pada kehidupan manusia. Aman dalam arti memberikan resiko kecelakaan dan terganggunya kesehatan yang minim. Nyaman dalam arti memberikan perasaan yang menyenangkan dan memberikan aspek beban fisiologis serta beban psikologis yang rendah. Tepat dalam arti memberikan solusi yang tepat dalam memenuhi kebutuhan manusia serta menggunakan sumber daya yang tepat. Mudah dalam arti memberikan kemudahan bagi pekerja dalam melaksanakan akttivitas dan pekerjaannya. Memberikan kepuasan dalam arti memberikan sebuah sistem yang dapat diterima dengan baik oleh manusia.

Antropometri, ialah sebuah ilmu yang mempelajari tata cara pengukuran dimensi tubuh manusia. Hasil dari pengukuran disebut data antropometri, yang akan dipergunakan dalam perancangan peralatan atau ruang untuk dipergunakan oleh manusia. Pembagian antropometri ada dua, yaitu antropometri statis dan antropometri dinamis. Antropometri statis untuk dimensi yang dikukur pada saat tubuh diam. Sedangkan antropometri dinamis untuk dimensi yang dikukur pada saat tubuh bergerak.

Fisiologi manusia adalah ilmu mekanis, fisik, dan biokimia fungsi manusia yang sehat, organ-organ mereka, dan sel-sel yang mereka tersusun. Tingkat utama fokus dari fisiologi adalah pada tingkat organ dan sistem. [ Sherwood, Lauralee (2010) (Hardcover). Human Physiology from cells to systems (edisi ke-7). Pacific Grove, CA: Brooks/cole. ISBN 978-0-495-39184-5. ]

Sistem otot dan tulang ialah sistem muskuloskeletal terdiri dari kerangka manusia (termasuk tulang, ligamen, tendon, dan tulang rawan) dan otot-otot melekat. Ini memberikan struktur dasar tubuh dan kemampuan untuk gerakan. [ https://id.wikipedia.org/wiki/Fisiologi_manusia ] 
Wrist pain is any discomfort in the wrist. It's often caused by carpal tunnel syndrome. Other common causes include wrist injury, arthritis, and gout. [ https://www.healthline.com/health/wristpain ].

Tahapan dalam perancangan terdiri dari : menjelajahi ide, mengurai masalah, membuat desain produk, pembuatan dan penyelesaian. [ https://dailysocial.id/post/lima-tahap-membuat-desainproduk-startup ]

Perancangan dan pengembangan sebuah produk dapat didasarkan melalui 4 jenis, yaitu : Pertama, Platform produk baru (merancang suatu keluarga produk baru berdasarkan platform baru) ; Kedua, Turunan dari platform produk yang telah ada (memperpanjang platform produk supaya lebih baik ; Ketiga, Peningkatan perbaikan untuk produk yang telah ada (penambahan atau modifikasi beberapa detil produk dari produk yang telah ada) ; Kempat, Pengembangan produk yang melibatkan produk yang sangat berbeda [Ulrich \& Eppinger, 2001].

\section{Pembahasan}

Dalam penelitian ini, digunakan kursi roda yang umum digunakan oleh masyarakat. Di tempat penjualan dikenal dengan nama kursi roda standart. Adapun dimensi kursi roda tersebut ialah sebagai berikut :

Tabel 1. Dimensi Kursi Roda Standart

\begin{tabular}{|c|c|}
\hline Dimensi & Ukuran \\
\hline Lebar kursi roda & $65.0 \mathrm{~cm}$ \\
\hline Lebar kursi roda saat dilipat & $24.0 \mathrm{~cm}$ \\
\hline Lebar sandaran & $47.0 \mathrm{~cm}$ \\
\hline Diameter ban belakang & $57.0 \mathrm{~cm}$ \\
\hline Diameter ban depan & $20.0 \mathrm{~cm}$ \\
\hline Tinggi posisi duduk dari lantai & $52.0 \mathrm{~cm}$ \\
\hline Tinggi total kursi roda & $\mathbf{8 9 . 0} \mathbf{~ c m}$ \\
\hline Panjang kursi roda & $106.0 \mathrm{~cm}$ \\
\hline Lebar alas duduk kursi roda & $47.0 \mathrm{~cm}$ \\
\hline Panjang alas duduk kursi roda & $39.0 \mathrm{~cm}$ \\
\hline Tinggi sandaran kursi roda & $45.0 \mathrm{~cm}$ \\
\hline Diameter pemutar & $54.0 \mathrm{~cm}$ \\
\hline
\end{tabular}

\begin{tabular}{|c|c|}
\hline Dimensi & Ukuran \\
\hline Diameter handle & $\mathbf{2 . 5} \mathbf{~ c m}$ \\
\hline Panjang handle & $\mathbf{9 . 5} \mathbf{~ c m}$ \\
\hline Lebar footrest & $16.5 \mathrm{~cm}$ \\
\hline Panjang footrest & $13.0 \mathrm{~cm}$ \\
\hline Panjang sandaran tangan & $42.0 \mathrm{~cm}$ \\
\hline Lebar sandaran tangan & $3.0 \mathrm{~cm}$ \\
\hline Tinggi sandaran tangan & $23.0 \mathrm{~cm}$ \\
\hline Tinggi minimal footrest & $32.5 \mathrm{~cm}$ \\
\hline Tinggi maksimal footrest & $52.5 \mathrm{~cm}$ \\
\hline Jarak jangkauan ke tuas rem & $49.5 \mathrm{~cm}$ \\
\hline Diameter besi & $2.2 \mathrm{~cm}$ \\
\hline
\end{tabular}

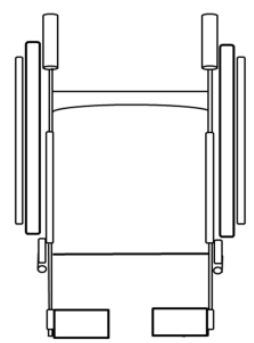

Tampak dari atas
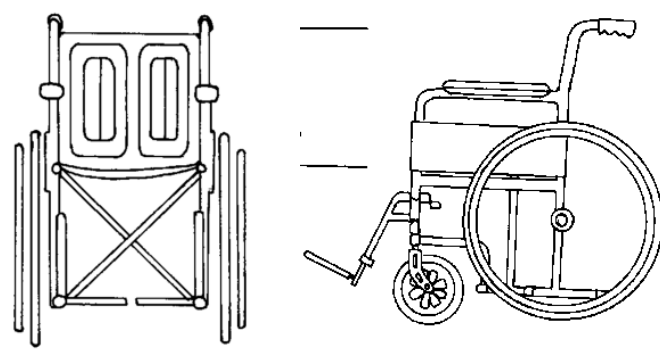

Tampak dari Samping

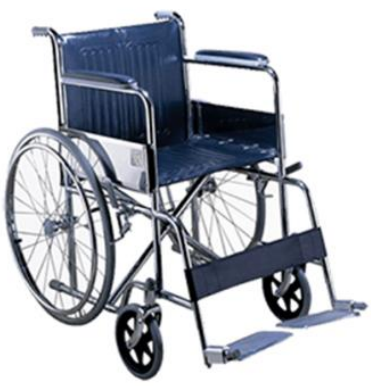

Tampak keseluruhan 3D 
Dimensi yang berpengaruh pada penelitian ini ialah :

- Tinggi total kursi roda, ialah tinggi handle dihitung dari lantai. Tinggi handle dari lantai sangat berhubungan dengan tinggi pendorong. Antropometri yang berhubungan ialah tinggi siku berdiri dari pendorong.

- Diameter handle, yang dimaksud ialah diameter pegangan kursi roda yang digunakan oleh pendorong untuk memegang dan mengendalikan kursi roda. Antropometri yang berhubungan dengan pendorong ialah genggaman tangan.

- Panjang handle, yang dimaksud ialah panjang dari pegangan kursi roda yang digunakan oleh pendorong untuk memegang dan mengendalikan kursi roda. Antropometri yang berhubungan dengen pendorong ialah lebar dari telapak tangan.

Tabel 2. Data Antropometri orng Indonesia

\begin{tabular}{|c|c|c|c|c|c|c|c|c|}
\hline \multirow{2}{*}{ DIMLNSI } & \multicolumn{4}{|c|}{ PRIA } & \multicolumn{4}{|c|}{ WANITA } \\
\hline & $5 \mathrm{th}$ & 50 th & 95th & S.D & 5 th & 50 th & 95 th & $5.1)$ \\
\hline 1. Panjang Tanģan ${ }^{\prime}$ & 163 & 176 & 189 & 8 & 155 & 168 & 181 & 8 \\
\hline 2. Panjang Teliapak Tangan $\vee$ & 92 & 100 & 108 & 5 & 87 & 9.4 & 101 & 4 \\
\hline 3. Panjang flu lari & 45 & 48 & 51 & 2 & 42 & 45 & 48 & $?$ \\
\hline 4. Panjang Jar Tclunjuk & 62 & 67 & 72 & 3 & 60) & 65 & 70) & 3 \\
\hline 5. Panjiang Jari Tenģalı & 70 & 77 & 84 & 4 & 69 & 74 & 79 & 3 \\
\hline 6. Panjang lari Manıs & 62 & 67 & 72 & 3 & 59 & 64 & 69 & 3 \\
\hline 7. Panjang,ari Kelingking . & 48 & 51 & 51 & 2 & 45 & 48 & 51 & 2 \\
\hline 8. Lebar lbu Jar: (II') & 19 & 21 & 23 & 1 & 16 & 18 & 20 & 1 \\
\hline 9. Tebal Ibu Jari (IPJ) & 1.9 & 21 & 23 & 1 & 15 & 17 & 19 & 1 \\
\hline 10. Lebar jari telunjuk (PIPI) & 18 & 20 & 22 & 1 & 15 & 17 & 19 & 1 \\
\hline 11 Teba! Jari Telunjuk (PIPT) & 10 & 18 & 20 & 1 & 13 & (5) & 17 & 1 \\
\hline $\begin{array}{l}12 \text { Lebar Telapak langan } \\
\text { (Metacarpal) }\end{array}$ & 74 & 81 & 88 & 4 & 68 & 73 & 78 & 3 \\
\hline $\begin{array}{l}\text { 13. Lebar Telapak Tangan } \\
\text { (sampai ibujari) }\end{array}$ & 88 & 98 & 108 & 6 & 82 & 89 & 96 & 4 \\
\hline $\begin{array}{l}\text { 11. Lebar Telapak Tangan } \\
\text { (mirimum) }\end{array}$ & 68 & 75 & 82 & 4 & 64 & 59 & 74 & 3 \\
\hline $\begin{array}{l}\text { 15. Tebal Telapak Tangan } \\
\text { (Metacarpal) }\end{array}$ & 28 & 31 & 34 & 2 & 25 & 27 & 29 & 1. \\
\hline $\begin{array}{l}16 \text { Tebal Telapak Tangan } \\
\text { (sampal tbu jari) }\end{array}$ & 41 & 48 & 47 & 2 & 41 & 44 & 47 & 2 \\
\hline $\begin{array}{l}\text { 17. Diamete: (ienggam } \\
\text { (maksimum) }\end{array}$ & 45 & 48 & 51 & 2 & 43 & 46 & 49 & 2 \\
\hline $\begin{array}{l}\text { 18. Lebar Maksimum (tbu Jari } \\
\text { ke Jari Kflingking) }\end{array}$ & $17 ?$ & 192 & 206 & y & 164 & 184 & 199 & 9 \\
\hline $\begin{array}{l}19 \text { Lebar Fungsional Maksj- } \\
\text { mum: (lbu Jari ke Jari lain) }\end{array}$ & 122 & 132 & 142 & 6 & 113 & 123 & 134 & 6 \\
\hline $\begin{array}{l}\text { 20. Segi Empat Minimum yang } \\
\text { dapat dilewati Telapak } \\
\text { Tangan }\end{array}$ & 57 & 62 & 67 & 3 & 51 & 56 & 61 & 3 \\
\hline
\end{tabular}

(Sumber : Buku Konsep Dasar dan Aplikasinya, Eko Nurmianto, 2004)

Dari hasil pengukuran handle pendorong kursi roda, didapatkan dimensi sebagai berikut :

- Panjang handle pendorong kursi roda sebesar $9.5 \mathrm{~cm}$.

- Diameter handle pendorong kursi roda sebesar $2.5 \mathrm{~cm}$, atau sekitar 1".

Dimensi Handle. Untuk memperoleh panjang handle pendorong kursi roda yang optimal, artinya dapat dengan nyaman digunakan oleh orang yang bertelapak tangan kecil atau bertelapak tangan 
besar, maka digunakan data antropometri lebar telapak tangan ( metacarpal ) dengan persentil maksimal (95\%). Patokan yang dipakai ialah minimal. Berdasarkan data antropometri orang Indonesia yang didapatkan dari buku yang berjudul Ergonomi, Konsep Dasar dan Aplikasinya, karangan Nurmianto, Eko. 2004, didapatkan untuk persentil maksimal lebar telapak tangan (metacarpal) orang Indonesia ialah $88 \mathrm{~mm}$ atau $8.8 \mathrm{~cm}$. Artinya untuk panjang handle pendorong kursi roda minimal $8.8 \mathrm{~cm}$. Dengan ukuran aktual sepanjang $9.5 \mathrm{~cm}$, maka dapatlah disimpulkan bahwa ukuran panjang handle pendorong kursi roda sudah masuk kategori nyaman (tidak kependekan, khususnya untuk orang yang memiliki tangan besar).

Untuk diameter handle pendorong kursi roda, digunakan data antropometri Diameter Genggam dengan persentil rata-rata $(50 \%)$, agar baik orang yang bertelapak tangan lebar maupun kecil mudah dalam menggenggam handle tersebut. Patokan yang digunakan ialah kurang lebih, dengan allowance $5 \mathrm{~mm}$. Berdasarkan data antropometri orang Indonesia, didapatkan untuk persentil ratarata Diameter Genggam orang Indonesia ialah $47 \mathrm{~mm}$, atau $4.7 \mathrm{~cm}$. Artinya untuk kenyamanan pengguna, sebaiknya diameter handle kursi roda antara $4.2-5.2 \mathrm{~cm}$. Dengan diameter aktual sebesar $2.5 \mathrm{~cm}$, maka diameter handle pendorong kursi roda dinilai terlalu kecil. Diameter handle kursi roda yang terlalu kecil bisa mengakibatkan kekuatan cengkraman tangan pada handle berkurang.

Posisi handle pendorong kursi roda. Bila kita cermati, posisi handle adalah tegak lurus sandaran kursi roda. Bagi pendorong hal ini mengakibatkan kesakitan pada lengan, terutama pada pergelangan tangan. Kesakitan pda pergelangan tangan muncul terutama bila pendorong mendoron kursi roda pada durasi yang lama dan/atau beban dorong yang tinggi (misalnya : beban berat, jalan menanjak atau jalan tidak rata).
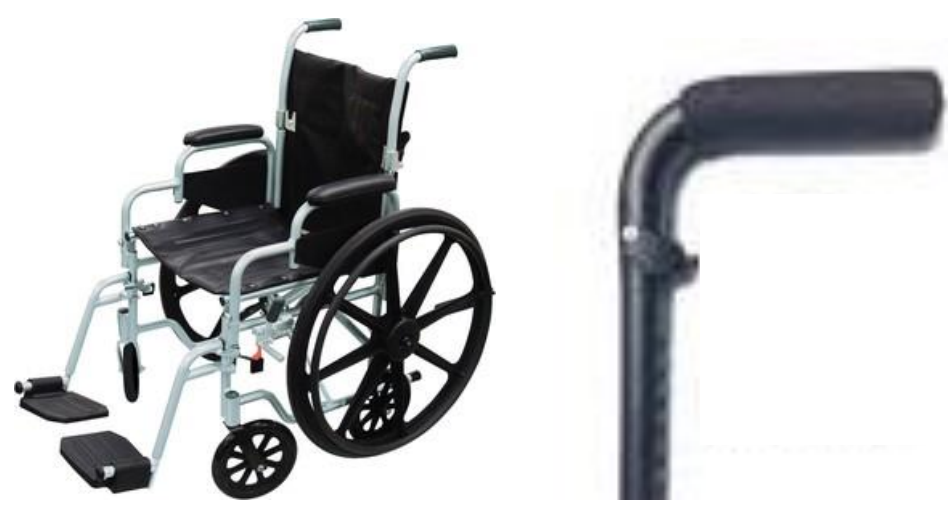

Gambar 2. Gambar Posisi handle kursi roda secara umum

Bagi orang yang berpostur tinggi, maka akan terlihat resultan gaya dorong ke atas dan ke bawah. Dimana, seharusnya daya dorong terfokus pada daya horizontal sejajar dengan arah gerakan kursi roda. (Gambar 3).

Bagi orang yang berpostur pendek, memang terlihat arah daya dorong hampir sejajar dengan arah gerakan kursi roda, akan tetapi pergelangan tangan tertarik lebih ke bawah. (Gambar 4). 

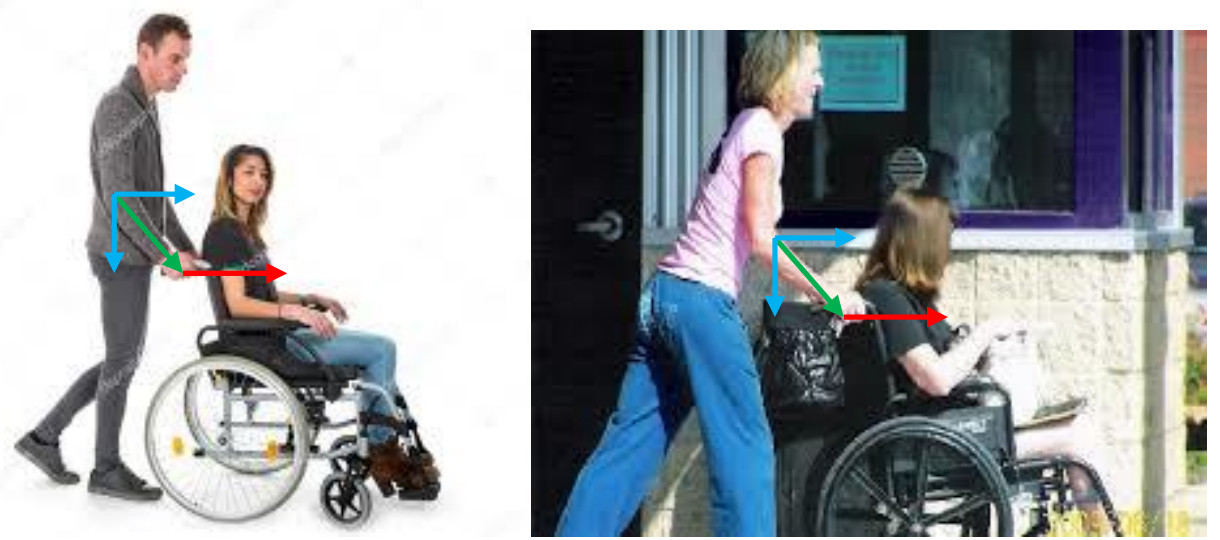

Gambar 3. Arah dorong ke kursi roda dan posisi tangan pendorong (pendorong memiliki postur yang tinggi)
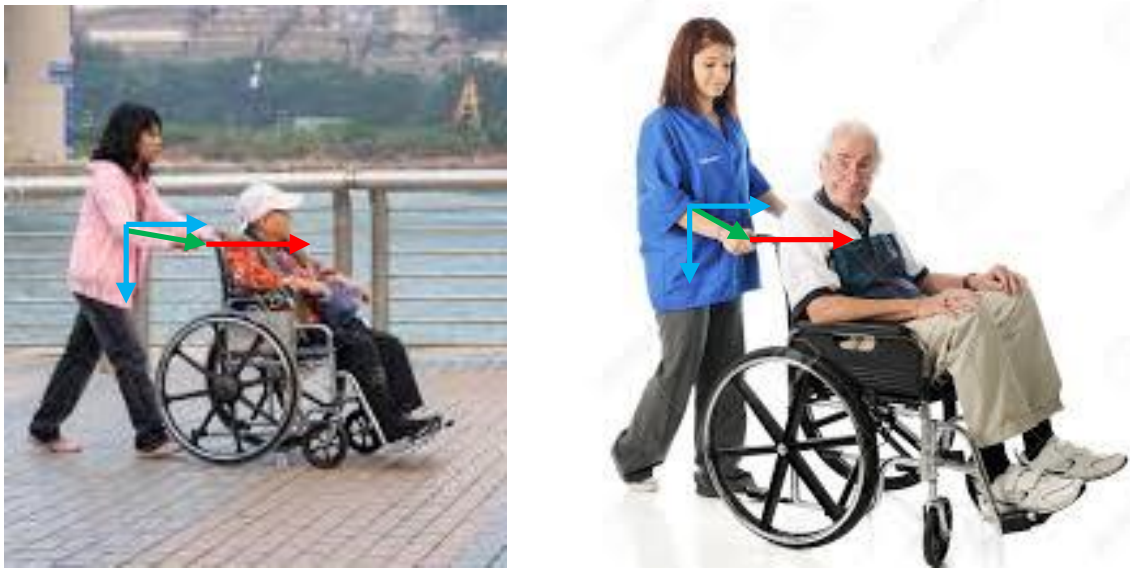

Gambar 4. Arah dorong ke kursi roda dan posisi tangan pendorong (pendorong memiliki postur yang pendek)
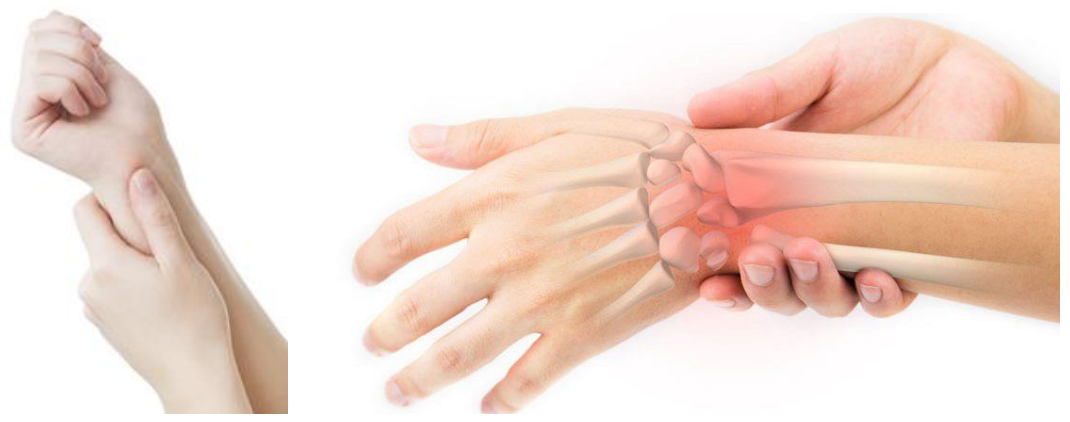

Gambar 5. Titik sakit pendorong kursi roda 

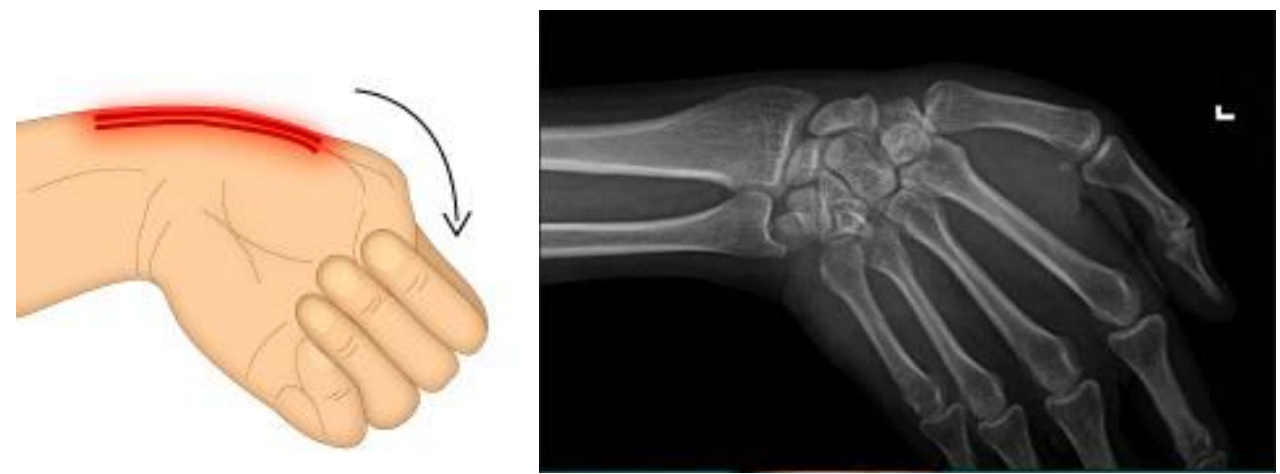

Gambar 6. Posisi tangan pada saat memegang handle pendorong kursi roda

Dengan posisi handle pendorong kursi roda seperti ini, akan mengakibatkan nyeri pada lengan, khususnya pada pergelangan tangan. Apalagi bila pendorong diharuskan mendorong kursi roda pada permukaan yang tidak rata atau menanjak.
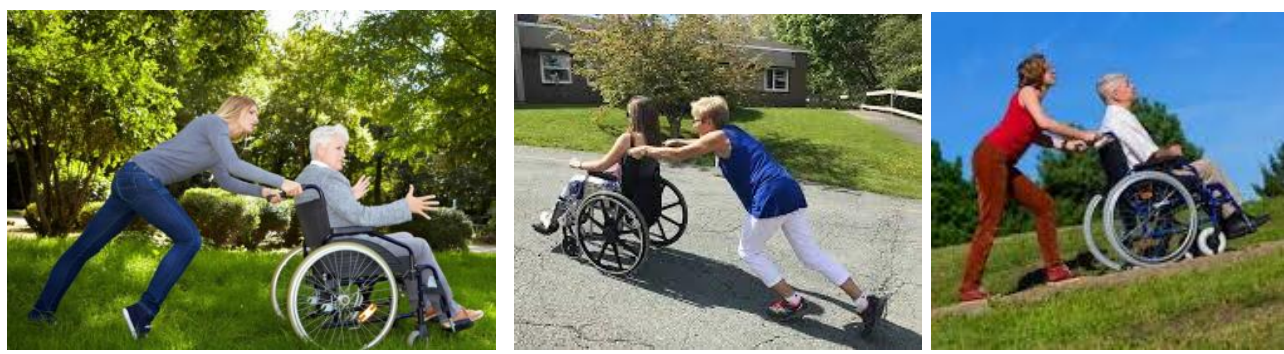

Gambar 7. Posisi tubuh pada saat mendorong kursi roda pada permukaan yang tidak rata atau menanjak. (perhatikan posisi pergelangan tangan)

Untuk permukaan yang menurun, pendorong diharuskan menahan kursi roda. Permukaan handle pendorong kursi roda yang biasanya licin ( terbuat dari karet mengkilap ) dan tidak bertekstur, bisa mengakibatkan mudah terlepas.

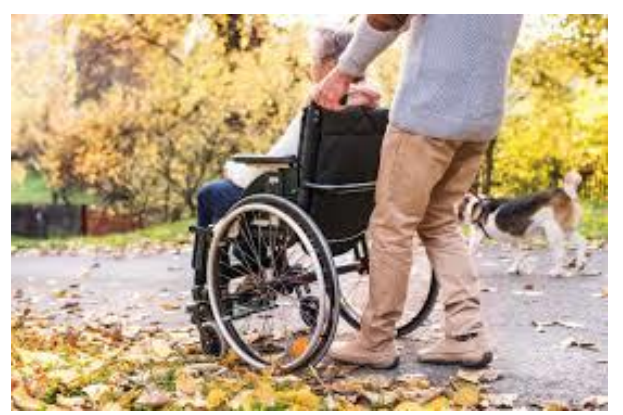

Gambar 8. Posisi tubuh pada saat menhan kursi roda pada permukaan yang menurun menanjak (perhatikan posisi genggaman tangan pada handle)

Dari hasil analisa, maka dirancang handle pendorong kursi roda dengan fokus pada :

a. Sudut kemiringan handle pendorong kursi roda.

Sudut kemiringan handle pendorong kursi roda sebaiknya diberikan yang adjustable. Karena dengan sudut kemiringan yang adjustable, akan membuat kenyamanan pada postur pendorong yang pendek maupun yang postur pendorong yang tinggi. (Gambar 9)

b. Permukaan handle pendorong kursi roda.

Permukaan handle pendorong kursi roda sebaiknya dibuat tidak licin. Pengunaan bahan karet tidak disarankan, karena akan membuat telapak tangan pendorong terasa panas. Oleh karena itu, akan lebh baik dibuat dengan bahan busa yang menyelimuti gagang handle. 


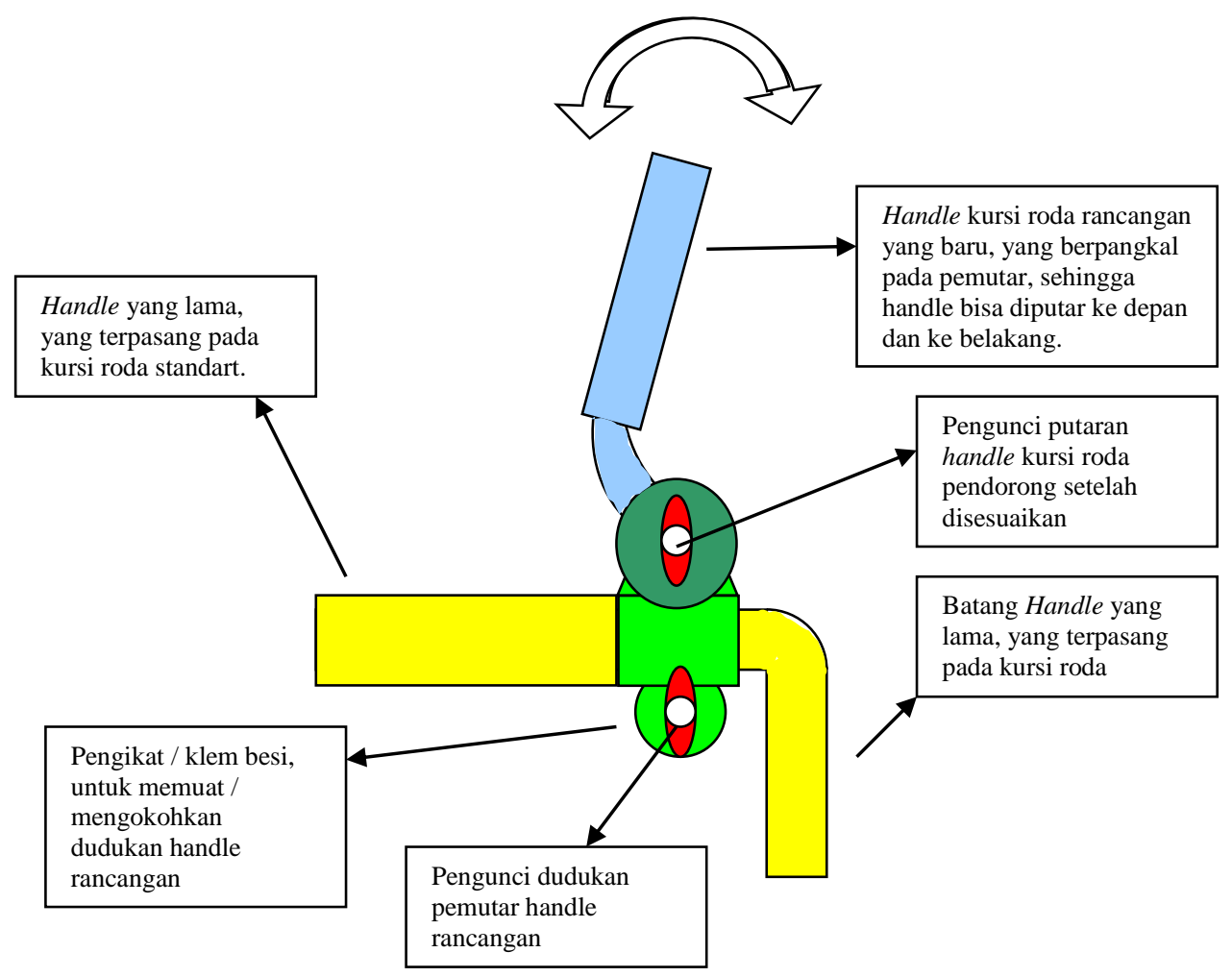

Gambar 9. Rancangan Handle, pemutar dan dudukannya pada batang besi pendorong kursi roda standart

Rancangan handle pendorong kursi roda dirancang untuk tidak merubah bentuk handle kursi roda yang standart. Rancangan handle pendorong kursi roda dirancang sebagai peralatan tambahan untuk dipasangkan pada handle kursi roda yang standart (lama).

\section{Kesimpulan}

Berdasarkan penelitian ini dapatlah disimpulkan bahwa pendorong kursi roda sangat mempengaruhi keselamatan pemakai kursi roda. Selain itu, pendorong kursi rodapun perlu diperhatikan mengenai kesehatan anggota badannya, khususnya pada pergelangan tangannya. Agar supaya tidak mengalami cedera pada saat mendorong kursi roda. Keselamatan pendorong mempengaruhi keselamatan pemakai ( pasien ) kursi roda.

Dari analisa bentuk rancangan handle pendorong kursi roda, maka didapatkan keterbatasanketerbatasannya, yaitu :

- Ukuran panjang handle pendorong kursi roda tidak disarankan lebih kecil dari $8.8 \mathrm{~cm}$.

- Ukuran diameter handle pendorong kursi roda disarankan berukuran antara $4.2-5.2 \mathrm{~cm}$.

- Permukaan handle pendorong kursi roda sebiknya diberikan busa, sehingga nyaman untuk dipegang.

- Sudut posisi handle pendorong kursi roda tidak semestinya tegak lurus kursi roda. Hal ini untuk dua tujuan :

- Pada saat mendorong, tenaga yang disalurkan bisa lebih terarah sejajar dengan arah maju kursi roda. Hal ini terlebih sangat diperlukan pada saat mendorong dipermukaan yang tidak rata atau menanjak.

- Pada saat menahan kursi roda pada saat di permukaan yang menurun, handle yang terancang cukup berbahaya karena bisa terlepas. Penahanan hanya pada kekuatan cengkraman pada handle pendorong kursi roda. Terkecuali bila kursi roda dilengkapi dengan rem ( pada kursi roda standar, rem pada handle pendorong kursi roda tidak tersedia ). 
- Dengan sudut kemiringan handle pendorong kursi roda ke arah atas, maka akan lebih mudah bagi pendorong kursi roda untuk mendorong, membelokkan ataupun menahan kursi roda dengan aman dan nyaman.

- Sudut kemiringan dari handle rancangan dapat di adjustable, sehingga bisa menyesuaikan kenyamanan pada saat mendorong, baik pendorong dengan postur tinggi maupun postur pendek.

Dengan dirancangnya handle pemndorong kursi roda yang baru, akan meningkatkan kenyamaman dan keamanan baik dari sisi pasien dan dari sisi pendorong.

\section{Daftar Pustaka}

Fisiologi manusia, https://id.wikipedia.org/wiki/Fisiologi_manusia, diakses pada Senin, 14 Oktober 2019, pukul 09.00 WIB

Natalie Phillips and Ana GotterPossible, Causes of Wrist Pain and Treatment Tips, https://www.healthline.com/health/wrist-pain, diakses pada Senin, 14 Oktober 2019, pukul 10.00 WIB

Nurmianto, Eko, (2003), Ergonomi : Konsep Dasar dan Aplikasinya, Edisi Pertama, Guna Widya, Surabaya.

Sherwood, Lauralee, (2010), (Hardcover). Human Physiology From Cells to Systems, edisi ke-7, Pacific Grove, CA: Brooks/cole. ISBN 978-0-495-39184-5.

Silalahi, B. Rumondang, N.B Bennet, (1985), Manajemen Kesehatan dan Keselamatan Kerja, Seri Manajemen, Cetakan Pertama, Institut Pendidikan dan Pembinaan Manajemen (IPPM), Jakarta.

Suma'mur P.K., (1987), Kesehatan dan Keselamatan Kerja dan Pencegahan Kecelakaan, Cetakan ke-3, CV. Haji Masagung, Jakarta.

Sutalaksana, Iftikar Z., Ruhana Anggawisastra, John H. Tjakraatmadja, (1979), Teknik Tata Cara Kerja, Departemen TI - ITB.

Ulrich, Karl T., Steven D. Eppinger, (2000), Perancangan dan Pengembangan Produk, Salemba Teknika, Bandung.

Ulrich K.T., Epinger S.D., (2000), Product Design and Devolopment, 2nd edition, McGraw-Hill, Singapore.

Weimer Don, Ph. D., (1993), Handbook of Ergonomic and Human Factors Tables, Prentice Hall, Emglewood Cliffs, New Jersey.

Yenny Yusra, Lima Tahap Membuat Desain Produk Startup, https://dailysocial.id/post/lima-tahapmembuat-desain-produk-startup, diakses pada Senin, 14 Oktober 2019, pukul 09.30 WIB 